\title{
GASTRIC TRANSPOSITION IN LONG- GAP ESOPHAGEAL ATRESIA
}

The reported incidence of esophageal atresia (EA) with or without tracheo-esophageal fistula varies widely from 1 in 2440 live births in Finland to 1 in 4500 births in the United States. The long-gap esophageal atresia (LGEA) constitutes about 8-9\% of all EA with or without tracheo- esophageal fistula and it is a big challenge for pediatric surgeon. Usually in infants with isolated EA or EA with upper pouch fistula, the upper pouch is high and the distance between the upper and lower esophageal segments limit the ability of easily complete tension free end to end esophagoesophagostomy. Although much has been said and written about the subject, there is no precise definition of LGEA. There are many definitions according to different authors.

(i) Too long gap for a true primary repair ( J.E.Foker)

(ii) No distal fistula -measured gap of at least 6 vertebrae (L. Spits)

(iii) Atresia without distal fistula ( N.M. A. Bax)

(iv) Gap more than 3 vertebrae (A.F Hasma)

LGEA most of the time recognized at thoracotomy. Although it is obvious that the patient's own esophagus is the best esophagus and despite the many methods and innovations developed to achieve esophageal continuity in infant with EA, the esophagus may need to be replaced if these methods fail. Numerous operative procedures have been described for esophageal replacement in infants with EA. The Choice of esophageal substitute depends on many factors. Colon replacement, or ileocolon has been widely practiced for many years as a method of esophageal replacement. Either the right or left colon can be placed substernally or behind the hilum of the lung or the right or left side. Vagotomy and a gastric drainage procedure are typically performed to avoid stricture or ulceration at the cologastric anastomosis. Several complications occur after colonic interposition , including cervical anastomotic leak ( $30 \%$ to $50 \%$ of cases), stricture, and intrathoracic redundant colon with stasis, gastric reflux, respiratory problems, and diarrhea, Some surgeons favor a reserved gastric tube as a substitute, in this procedure a tubularized portion of the greater curvature is brought up to the cervical esophagus in the substernal or retrohilar position. Complications are similar to those described for colonic interposition. The jejunum has also been used for esophageal replacement both in a Roux-en-Y fashion and as a free graft with micro vascular anastomosis. Gastric transposition has more recently become a well established and successful esophageal substitute in infants with EA.

Although esophageal replacement is possible in newborns, the procedure should generally be delayed untill the baby is thriving and weights is at least 5 $\mathrm{Kg}$. and before replacement baby is managed by cervical esophagostomy and feeding gastrostomy . In the interim, it is important to stimulate the swallowing reflex by offering sham of oral feedings during regular gastrostomy feedings .

\section{Gastric Transpositions-}

In 1922, kummell reported mobilization of the esophagus in two patients by bluntly freeing the esophagus with fingers introduced from cervical and abdominal wounds. The stomach was then transplanted into the esophageal bed and the esophagus was anastomosed to the stomach. Although both patients died, this was the first attempt at gastric transposition by means of the meditational route. In 1938, Adams and Phemister successfully resected a carcinoma in the lower thoracic esophagus of a 53 year old patient and restored 
continuity by esophagogastrostomy . In 1944 Garlock's successful re-establishment of esophagogastric continuity after resection of the esophagus for carcinoma of the middle third in a 58 years old man was reported. At follow-up the only complication was regurgitation in the recumbent position, and this problem was controlled by sleeping on two pillows. In 1945 Sweet recorded 12 esophageal resections with esophagogastric anastomosis above the arch of the aorta, and in 1948 he described the successful application of his technique after resection of a carcinoma of the upper thoracic esophagus with anastomosis of the stomach to the cervical esophagus. Soon thereafter, successful pharyngogastrostomy was described. In 1980 Atweel and Harrision reported six children who underwent gastric transposition ; two died but good long turm results were achieved in the other four patients. In 1987 Valente et al, reported 21 cases, one died. In 1991 Marujo et al. also reported 21 cases with almost same outcome. In1995 Spitz managed 83 cases, only six died. In 2002 Harsol reported 41 cases without any death . but with good longterm results .

In 2004, L. Spitz et al. have reported good to excellent outcomes in $90 \%$ of more than 173 (127 with EA) infants and children in whom gastric transposition method of replacement was used. The survival rate was $94.8 \%$, the incidence of anastomotic leak was $12 \%$, and there was no deterioration in function over a 10 year follow -up.

Replacement of the esophagus by gastric transposition is currently the procedures of choice in infant with long-gap EA due to simpler procedures and long-term good outcomes.

\section{Professor Dr. Md. Abu Jafor}

Head, Department of Pediatric Surgery

Sir Salimullah Medical College \& Mitford Hospital, Dhaka

\section{Reference :}

1. Kluth D: Atlas of esophageal atresia. J Pediatr surg $1976 ; 11: 901$.

2. Coran AG: Ultra-long gap esophageal atresia: How long is long ? Ann Thorac surg 1994;57:528.
3. Ein $\mathrm{SH}$, Shandling B: Pure esophageal atresia : A50 year review . J Pediatr. surg 1993;28:1147.

4. Erdogan E, Emir H, Eroglu E,et al. Esophageal replacement using the colon. A15 years review. Pediatr surg int 2000;16:546.

5. Cusick El, Bachelor AAspicer RD: Development of a technique for jejunal interposition in longgap esophageal atrisia. J Pediatr surg int. 1993;28:990.

6. West KW . Vane DW, Grosfeld JL : Esophageal replacement in children : Experience with thirty one cases. surgery 1986;100:751.

7. Lessin MS, Wesselheoft CW, lucks FI:et al : primary repair long-gap esophageal atresia by mobilization of the distal esophagus. Eur $\mathrm{J}$ Pediatr surg. 1999;9:369.

8. Deurlbo JA, Ekkelkamp S, Schoorl M, et al: Gastroesophageal atresia: Historical evolution of management and results in 371 Patients .Ann Thorac surg 2002;72:267.

9. Borgnon J, Touniam $P$, et al:Esophygeal replacement in children by an isoperistaltic gastric tube:A 12 year experience. Pediatr surg int: 2004;20:829.

10. Valente A, Breereton RJ: Mackersie A: Esophageal replacement with whole stomach in infants and children. J Prediatr surg 1987;22:913.

11. Hirschl RB: Gastric transposition for esophageal replacement in children : Experience with 41 consecutive cases with special emphasis on esophasis on esophageal atresia , Ann surg 2002;236:680.

12. Hirschil RB: Gastric transposition for esophageal replacement in children : Experience with 41 consecutive cases with special emphasis on esophageal atresia. Ann surg 2002;236:531.

13. Bagolan $\mathrm{P}$, lacobelli $\mathrm{Bd}$. $\mathrm{B}$, De Angelis $\mathrm{P}$, et. al. Long-gap. esophageal atriesia and esophageal replacement: Moving toward a separation ? J Pediatr surg: 2004;188:328. 
14. Spitz L: Gastric replacement of the esophagus. In Spitz L, Coran AG (eds): Pediatric surgery; $5^{\text {th }}$ ed. London , Gapman \& Hall, 1995.

15. Spitz L, Kiely E, Pierro A : Gastric transposition in children a 21-year Experience. J Pediatr. surg. 2004;39:276.

16. C. M Harman and Arnold G coran 2006: Congenitul Anomalies of the Esophagus, PP.
1051 -74 . In: JL Grosfeld, JA O'Neill, Jr, Eric W : Fonkalsrud, Arnold G coran (eds), Pediatric surgery, $6^{\text {th }}$ ed. Mosby, Philadephia.

17. L. Spitz, 2006. Esophageal replacement, PP 1093-1104 In: JL Grosfeld, JA O’Neill, Jr, Eric W : Fonkalsrud, Arnold G coran (eds), Pediatric surgery , $6^{\text {th }}$ ed. Mosby, Philadephia.

18. internet: www.ncbi.nlm.nih.gov/pubmed en.weikipedia.org/wiki/Esophageal .atresia. 